\title{
Pengaruh Status Identitas terhadap Orientasi Masa Depan Area Pekerjaan
}

\author{
Novita Sari, Tarsono, Elisa Kurniadewi \\ UIN Sunan Gunung Djati Bandung, Jl. A.H. Nasution No. 105 Bandung \\ e-mail: novitasari.prof@gmail.com
}

\begin{abstract}
Based on the observation of the researcher, the lack of future orientation amongst students, particularly in the area of career, led by deciding on study program was not deliberately when enroll in the university. The research intended to obtain empirical data on the effect of the identity status on future orientation of the work area among students of the psychology program. The method used correlation study. The results showed that there was a significant influence of the identity status on the future orientation in working area. $R$ square $\left(R^{2}\right)$ was 0.314 , it meant $31.4 \%$ of the variation of the future orientation in working area influenced by the identity status. Three of the four identity statuses have a significant influence, namely the identity of achievement, the diffuse, and the moratorium. In despite there was correlation between foreclosure identity with future-orientation in working area however there was not significant effect.
\end{abstract}

Keywords: future orientation, identity status, student, working area

\begin{abstract}
Abstrak
Berawal dari pengamatan peneliti mengenai kurangnya perencanaan yang matang para mahasiswa ketika memilih jurusan kuliah sehingga mahasiswa kurang memiliki orientasi masa depan, khususnya di area pekerjaan. Penelitian ini dimaksudkan untuk memperoleh data empirik mengenai pengaruh status identitas terhadap orientasi masa depan area pekerjaan pada mahasiswa Psikologi UIN SGD. Pendekatan penelitian yang digunakan adalah pendekatan kuantitatif dengan metode korelasional yang bersifat kausal. Hasil penelitian menunjukkan bahwa ada pengaruh yang signifikan dari status identitas terhadap orientasi masa depan area pekerjaan. Diperoleh $R$ square $\left(R^{2}\right)$ sebesar 0,314 , hal ini berarti $31,4 \%$ variasi dari orientasi masa depan area pekerjaan dipengaruhi oleh variabel status identitas. Tiga dari empat status identitas memberikan pengaruh yang signifikan yaitu identitas achievement, diffuse, dan moratorium. Sedangkan identitas foreclosure tidak berpengaruh secara signifikan, namun dari hasil uji korelasi ada hubungan antara identitas foreclosure dengan orientasi masa depan area pekerjaan.
\end{abstract}

Kata Kunci: orientasi masa depan, status identitas, mahasiswa

\section{Pendahuluan}

Pemerintah menyelenggarakan sis-tem pendidikan Nasional dalam rangka mencerdaskan kehidupan bangsa serta memajukan ilmu pengetahuan dan teknologi. Pendidikan tinggi sebagai salah satu bagian dari sistem pendidikan Nasional memiliki peran strategis dalam mewujudkan keinginan tersebut. Salah satu tujuan pendidikan tinggi yang tertera pada UU Republik Indonesia No. 12 tahun 2012 pasal 5 tentang Pendidikan Tinggi, yaitu menghasilkan lulusan yang dapat menguasai cabang ilmu pengetahuan dan/atau teknologi untuk memenuhi kepentingan
Nasional dan meningkatkan daya saing bangsa.

Perguruan tinggi sebagai lembaga yang menyelenggarakan pendidikan tinggi bertugas untuk mengerahkan seluruh civitas akademiknya agar mengoptimalkan segala kemampuannya dalam upaya mencerdaskan kehidupan bangsa melalui pembelajaran yang dilakukan dalam perkuliahan. Sebagai seorang mahasiswa yang menjadi bagian dari civitas akademika memiliki tanggung jawab untuk mengemban tugas sebagai generasi penerus bangsa yang menguasai cabang keilmuan sesuai bidangnya dan kemudian nantinya ketika 
sudah lulus dari perguruan tinggi tersebut dapat menghadapi persaingan global.

Untuk menghadapi tuntutan tersebut tentunya mahasiswa harus mulai menyiapkan masa depannya dan menentukan tujuan yang hendak dicapai dimasa mendatang dan menyusun strategi-strategi untuk mencapai tujuan tersebut. Salah satu tujuan yang harus mulai ditentukan adalah dalam bidang pekerjaan dan karir, karena mahasiswa sedang berada pada tahap perkembangan masa remaja akhir yang sebentar lagi akan memasuki masa dewasa awal yang mengharuskan seseorang sudah mulai bekerja.

Dengan demikian seorang mahasiswa yang berada pada masa remaja akhir idealnya sudah memiliki tujuan dan rencana yang jelas dalam bidang pekerjaan dan karir untuk masa depannya. Hal ini sejalan dengan pendapat Havighurst (dalam Hurlock, 1980) yang menyatakan bahwa salah satu tugas perkembangan seorang remaja adalah mempersiapkan karir ekonomi. Selain itu banyak ahli psikologi perkembangan yang menyatakan bahwa remaja merupakan suatu periode untuk mempersiapkan kehidupan dewasa (Call, Reidel, Hein, McLoyd, Peterson, \& Kipke, 2002 dalam Beal, S.J., 2011). Nurmi (2004, dalam Beal, S.J) menyatakan bahwa pada masa remaja seseorang harus mendapatkan pengalaman yang dapat membantu mereka untuk membentuk harapan mereka di masa depan, yang meliputi persepsi berbagai kemungkinan dan peluang yang dapat diperoleh.

Mereka yang tidak memiliki tujuan yang jelas untuk masa depannya akan cenderung kebingungan dan hanya hidup mengikuti alur yang ada tanpa memiliki tujuan yang jelas dalam hidupnya. Berbeda dengan mereka yang sudah memiliki tujuan yang jelas dalam hidupnya akan lebih memiliki perencanaan yang matang dalam hidupnya sehingga di masa depan akan mendapat karir lebih baik dan mampu bersaing di persaingan global. Oleh karena itu idealnya seorang mahasiswa harus sudah memiliki orientasi masa depan yang jelas dalam bidang pekerjaan dan karirnya.

Pada kenyataannya tidak sedikit individu yang belum memiliki perencanaan dan orientasi masa depan yang jelas dalam hidupnya, mereka hanya menjalani kehidupan seperti air mengalir yan-g mengikuti arus yang tersedia tanpa mencoba membuat rencana hidupnya sendiri.

Pada Fakultas Psikologi UIN Bandung ditemukan bahwa diawal per-kuliahan sebagian besar mahasiswa belum memiliki orientasi masa depan yang jelas dan mereka belum benar-benar yakin dengan pilihannya pada jurusan Psikologi UIN Bandung. Terlihat dari jawaban mahasiswa ketika ditanya mengenai alasan mengapa kuliah di UIN Bandung. Berikut jawabannya "Pertamanya nggak UIN tapi SNMPTN UNPAD dan nggak lulus". "Jujur saja karena saya diterimanya disini jadi ini pilihan terakhir". "Karena pas SNMPTN lulusnya di UIN Bandung, jadi di ambil aja, males daftar-daftar lagi ke Universitas lain". "Nggak tau, kakak yang daftarin SNMPTN, aku Cuma ikut ujiannya aja" (Hasil angket pada bulan april 2015).

Hal ini juga terlihat dari jawaban mahasiswa saat ditanya kenapa memilih jurusan psikologi:"Tadinya bener-bener nggak punya niat masuk psikologi karena berniat ingin masuk ke kesehatan. Tapi terkendala lokasi yang jauh sehingga orang tua tidak mengijinkan karena tidak boleh ngekost. Akhirnya saya memilih psikologi karena menurut saya masih berhubungan dengan minat saya dan kalau kuliah di UIN Bandung masih dekat dengan rumah sehingga tidak perlu ngekost. Sampai sekarang saya masih menginginkan kuliah di jurusan kesehatan, namun karena orang tua tidak membolehkan kost jadi saya mengikuti orang tua.". "Karena tertarik pada psikologi dan menghindari matermatika" . "Sebenarnya dulu tuh pengennya masuk kesehatan makanya memilih jurusan IPA. Saat 
SNMPTN pernah memilih jurusan Kesehatan tapi karena tidak lulus akhirnya saya memilih Psikologi.". "Pertamanya sih gara-gara ngikutin kakak sepupu kuliah di psikologi juga". "Mungkin di awalnya bukan maksud utama masuk jurusan psikologi, Pada awalnya saya berminat di jurusan seni musik, sejarah dan jurusan sosiologi. Nah ketika itu Psikologi UIN sebagai alternatif terakhir. Saat menginjak semester 2 saya pernah mencoba fokus ke SNMPTN untuk mengejar jurusan yang saya inginkan yaitu seni musik sehingga IP saya menjadi turun. Karena saya merasa memiliki passion ke jurusan seni musik dan belum memiliki gambaran yang jelas terhadap jurusan psikologi yang sedang saya jalani. Karena tidak diterima dijurusan seni musik saat mengikuti SNMPTN sedangkan saya sudah menginjak semester 3 di psikologi akhirnya tidak ada pilihan lain selain mempertahankan apa yang sudah saya jalani di jurusan Psikologi" (Hasil wawancara pada bulan april 2015). Dari jawaban-jawaban yang diberikan oleh mahasiswa terlihat bahwa sebagian besar mahasiswa belum benarbenar yakin dengan jurusan Psikologi dan bahkan memilih Psikologi dikarenakan yang tersedia hanya itu atau sebagai pilihan terakhir.

Dari data-data tersebut menunjukkan bahwa pada saat semester awal sebagian besar mahasiswa belum memiliki perencanaan dan orientasi masa depan di bidang pekerjaan dan karir yang jelas. Menurut Nurmi (1989 dalam Beal, S.J., 2011) Orientasi masa depan adalah proses multidimensi dari motivasi, perencanaan dan evaluasi, dimana motivasi adalah minat seseorang terhadap suatu hal, perencanaan adalah bagaimana seseorang bermaksud untuk mewujudkan tujuan yang hendak dicapai di masa depan ,dan evaluasi adalah penilaian sejauh mana tujuan yang diharapkan individu tersebut dapa diwujudkan. Pada mahasiswa Fakultas Psikologi terlihat bahwa motivasi mereka masih rendah, demikian pula secara otomatis perencanaan dan evaluasi terhadap masa depan tentunya akan terpengaruhi.

Mahasiswa yang berada pada tahap perkembangan masa remaja akhir juga memiliki tugas perkembangan lain yaitu untuk menemukan identitasnya. Hal ini sesuai dengan yang diungkapkan oleh Erikson (dalam Santrock 2012) bahwa pada masa remaja, individu dituntut untuk menentukan keputusannya mengenai siapakah dirinya, bagaimanakah dirinya, tujuan apakah yang hendak diraihnya. Selanjutnya menurut Feist \& Feist (2010) masa remaja merupakan salah satu tahapan perkembangan yang paling penting karena diakhir periode ini seseorang harus sudah bisa memperoleh rasa ego identitas yang tetap. Individu yang telah mencapai identitasnya akan menjadi individu yang lebih mandiri dan bahagia serta akan mempermudah dalam melakukan tugas perkembangan berikutnya, sebaliknya apabila individu belum dapat mencapai identitasnya akan menjadi individu yang tidak memiliki pendirian yang mantap, kebingungan dan cenderung melebur dengan identitas kelompoknya karena tidak memiliki identitas diri yang tetap.

Marcia $(1980,1994)$ juga berpen-dapat: Teori perkembangan identitas Erikson terdiri dari empat status identitas, atau cara yang ditempuh dalam menye-lesaikan krisis identitas. Keempat status identitas itu adalah identity difusion, identity foreclosure, identity moratorium, dan identity achievement . Marcia mengklasifikasikan individu berdasarkan eksistensi atau sejauh mana krisis atau komitmen yang terjadi. Krisis didefinisikan sebagai periode perkembangan identitas di mana individu berusaha melakukan eksplorasi terhadap berbagai alternatif. Komitmen adalah penerimaan personal pada satu identitas dan menerima apa pun implikasi dari identitas itu. (Santrock, 2012, hal. 438-439)

Penjelasan dari keempat status tersebut adalah sebagai berikut : Identity diffusion adalah status seseorang diama ia 
belum pernah mengalami krisis dan juga belum membuat komitmen apapun. Identity foreclosure adalah status seseorang dimana ia membuat komitmen namun tidak pernah mengalami krisis. Identity moratorium adalah status seseorang yang berada pada pertengahan krisis namun komitmennya tidak ada atau hanya didefinisikan secara kabur. Identity achievement adalah status seseorang yang sudah mengalami krisis dan telah membuat komitmen (Santrock, 2012)

Proses eksplorasi identitas tersebut tentunya akan mempengaruhi orientasi masa depan dalam bidang pekerjaan dan karir mahasiswa. Karena ada tidaknya komitmen serta keputusan komitmen seseorang terhadap identitasnya akan menentukan minat dan perencanaan masa depan seseorang. Sejalan dengan hasil penelitian kualitatif Flores-Crespo (2007 dalam Jelenic, M., 2013) yang dilakukan terhadap 48 siswa dan 32 guru, FloresCrespo menemukan bahwa identitas mempengaruhi tingkah laku di kelas dan juga mempengaruhi pandangan terhadap orientasi masa depan tentang pilihan sekolah dan preferensi karir.

Dari fenomena yang telah dibahas sebelumnya peneliti bermaksud untuk melakukan penelitian yang berjudul "PENGARUH STATUS IDENTITAS TERHADAP ORIENTASI MASA DEPAN AREA PEKERJAAN (Penelitian terhadap Mahasiswa Fakultas Psikologi UIN Sunan Gunung Djati Bandung)".

\section{Metode Penelitian}

Penelitian ini menggunakan pendekatan kuantitatif, dengan metode korelasional yang hubungannya bersifat kausal atau sebab akibat. Variabel Independen dalam penelitian ini adalah status identitas. Marcia (1980 dalam Jelenic, M) menyatakan bahwa identitas merupakan self- constructed, koordinasi aktif dari motivasi, bakat dan keyakinan, memiliki ciri-ciri tersendiri yang melekat, sejarah pribadi yang muncul di akhir masa kanak-kanak. Menurut Marcia (1993) pembentukan identitas diri merupakan suatu proses penggabungan antara pengalaman, kepercayaan, dan identifikasi yang dimiliki pada masa kanak-kanak menjadi kesatuan yang unik dan akan semakin lebih atau tidak koheren, yang akan memberikan para dewasa awal baik perasaan keterkaitan dengan masa lalu maupun arah bagi masa yang akan datang. Marcia (1993) menyatakan bahwa pembentukan identitas diri dapat digambarkan melalui status identitas berdasarkan ada tidaknya eksplorasi (krisis) dan komitmen. Eksplorasi atau juga yang disebut krisis merupakan periode berusaha atau aktif bertanya untuk mencapai sebuah keputusan mengenai tujuan yang hendak dicapai, nilai-nilai dan keyakinankeyakinan. Status identitas terdiri dari identitas Achievement, Moratrium, Foreclosure, dan Diffuse.

Identity diffusion adalah individu yang belum mengalami krisis dan juga belum memiliki komitmen sehingga masih mengalami kebingungan identitas. Identity foreclosure adalah individu yang belum mengalami krisis namun sudah membuat komitmen, komitmen diperoleh dari mencontoh atau mengikuti orang tua. Identity moratorium adalah individu yang sudah mengalami krisis namun belum membuat komitmen, individu ini masih mempertimbangkan identitasnya atau pilihannya. Identity achievement adalah individu yang sudah mengalami krisis dan telah membuat komitmen, individu ini sudah menemukan identitasnya.

Variabel dependennya adalah orientasi masa depan area pekerjaan yaitu proses multidimensi dari motivasi, peren-canaan dan evaluasi, dimana motivasi adalah minat seseorang terhadap suatu hal, perencanaan adalah bagaimana seseorang bermaksud untuk mewujudkan tujuan yang hendak dicapai di masa depan ,dan evaluasi adalah penialalian sejauh mana tujuan yang diharapkan individu tersebut dapat diwujudkan (Nurmi, 1989 dalam Beal, S.J., 2011) 
Populasi dalam penelitian ini adalah mahasiswa Fakultas Psikologi UIN Bandung yang terdiri dari mahasiswa tingkat I hingga tingkat IV yang tercatat aktif berkuliah pada tahun 2016 yang berjumlah 586 mahasiswa. Karena populasi terdiri dari empat angkatan maka penentuan jumlah sampling menggunakan Proportionate Stratified Random Sampling. Pengumpulan data akan dilakukan menggunakan kuesioner atau angket. Teknik analisis data yang digunakan dalam penelitian ini adalah analisis regresi linier berganda yang digunakan untuk memprediksi seberapa besar perubahan nilai variabel dependen menggunkan data dari dua atau lebih variabel bebas yang sudah diketahui besarnya.

\section{Hasil Penelitian dan Pembahasan}

Sebelum dibahas hasil analisis inferensial terlebih dahulu peneliti akan membahas secara deskriptif gambaran status identitas pada mahasiswa Fakultas Psikologi UIN Sunan Gunung Djati Bandung. Dari empat status identitas disini peneliti hanya membahas identitas Diffuse dan identitas Achievement saja.

Yang pertama akan dideskripsikan distribusi skor Status identitas berdasarkan jenis kelamin, yang diringkas dalam Tabel1. Dari tabel 1 tersebut dapat dilihat bahwa selisih rata-rata status identitas antara laki-laki dan perempuan hanyalah sedikit saja. Terutama pada identitas Achievement selisih sangat tipis sekali, meskipun terlihat bahwa rata-rata laki-laki lebih tinggi. Untuk identitas diffuse ratarata skor laki-laki lebih tinggi pula.

Berikutnya adalah distribusi skor Status identitas berdasarkan tingkatan semester pada Tabel 2. Berdasarkan tingkatan semester dapat dilihat meskipun selisihnya tidak besar, namun rata-rata identitas diffuse semakin bertambah semester semakin berkurang. Begitupun sebaliknya rata-rata identitas achievement meningkat seiring ber-tambahnya semester.

Selanjutnya adalah distribusi skor Status identitas berdasarkan usia responden, yang diringkas dalam Tabel 3 . Sama seperti halnya distribusi skor berdasarkan tingkatan semester, distribusi skor berdasarkan usia juga menunjukkan bahwa seiring bertambahnya usia rata-rata skor identitas diffuse semakin berkurang. Dan begitupun sebaliknya rata-rata skor identitas achievement semakin meningkat semakin bertambahnya usia.

Kemudian selanjutnya adalah distribusi skor status identitas berdasarkan asal sekolah saat SMA (Tabel 4). Dari tabel tersebut terlihat bahwa tidak ada selisih yang signifikan dari rata-rata skor status identitas berdasarkan asal sekolah. Baik identitas diffuse maupun identitas achievement tidak ada selisih yang berarti.

Yang terakhir adalah distribusi skor status identitas berdasarkan jurusan saat SMA, yang disingkat dalam Tabel 5. Sama seperti skor rata-rata berdasarkan asal sekolah, selisis rata-rata berdasarkan jurusan saat SMA juga tipis.

\section{Gambaran Orientasi Masa Depan Area Pekerjaan pada Mahasiswa Fakultas Psikologi UIN Sunan Gunung Djati Bandung}

Pada bahasan ini, peneliti akan mendeskripsikan distribusi skor orientasi masa depan area pekerjaan berdasarkan kriteria sampel.

Untuk yang pertama akan dideskripsikan distribusi skor orientasi masa depan area pekerjaan berdasarkan jenis kelamin (Tabel 6). Dari data tersebut (Tabel 6) dapat dilihan bahwa rata-rata orientasi masa depan antara laki-laki dan perempuan hanya memiliki selisih sangat tipis, tapi rata-rata orientasi masa depan perempuan lebih besar dari rata-rata lakilaki. 
Tabel 1

Distribusi skor Status Identitas berdasarkan Jenis Kelamin

\begin{tabular}{cccccc}
\hline & \multicolumn{5}{c}{ Group Statistics } \\
& Jenis Kelamin & N & Mean & Std. Deviation & Std. Error Mean \\
\hline \multirow{2}{*}{ Diffuse Identity } & $\mathrm{L}$ & 55 & 46.9865 & 5.35514 & .72209 \\
& $\mathrm{P}$ & 168 & 45.3012 & 5.47276 & .42223 \\
\multirow{2}{*}{ Achievment Identity } & $\mathrm{L}$ & 55 & 54.8260 & 6.38939 & .86155 \\
& $\mathrm{P}$ & 168 & 54.1310 & 5.45883 & .42116 \\
\hline
\end{tabular}

Tabel 2

Distribusi skor Status Identitas berdasarkan Tingkat Semester

\begin{tabular}{|c|c|c|c|c|c|}
\hline & & $\mathrm{N}$ & Mean & Std. Deviation & Std. Error \\
\hline \multirow{3}{*}{ Diffuse Identity } & 2 & 59 & 48.8528 & 5.41082 & .70443 \\
\hline & 6 & 55 & 46.1910 & 5.43628 & .73303 \\
\hline & 8 & 53 & 43.6846 & 4.37056 & .60034 \\
\hline \multirow{4}{*}{ Achievment Identity } & 4 & 56 & 53.7927 & 4.84491 & .64743 \\
\hline & 6 & 55 & 54.5130 & 6.52124 & .87932 \\
\hline & 8 & 53 & 55.4005 & 5.34903 & .73475 \\
\hline & Total & 223 & 54.3024 & 5.69532 & .38139 \\
\hline
\end{tabular}

Tabel 3

Distribusi skor Status Identitas berdasarkan Usia

\begin{tabular}{lccccc}
\hline & & & & & \\
& & $N$ & Mean & Std. Deviation & \\
\hline & $17-19$ & 97 & 46.6995 & 5.78562 & .58744 \\
Diffuse Identity & $20-21$ & 95 & 45.1120 & 5.16824 & .53025 \\
& $>22$ & 31 & 44.4957 & 5.06363 & .90945 \\
Achievment Identity & Total & 223 & 45.7168 & 5.48056 & .36701 \\
& $17-19$ & 97 & 53.7621 & 5.27409 & .53550 \\
& $20-21$ & 95 & 54.6207 & 6.20796 & .63692 \\
& $>22$ & 31 & 55.0178 & 5.33588 & .95835 \\
& Total & 223 & 54.3024 & 5.69532 & .38139 \\
\hline
\end{tabular}

Tabel 4

Distribusi skor Status Identitas berdasarkan Asal Sekolah

\begin{tabular}{llcrrr}
\hline & & & & & \\
& & N & Mean & Std. Deviation & \\
\hline \multirow{5}{*}{ Diffuse Identity } & SMA & 131 & 45.8134 & 5.66633 & .49507 \\
& MA & 80 & 45.5600 & 5.37566 & .60102 \\
& SMK & 12 & 45.7083 & 4.34889 & .25542 \\
& Total & 223 & 45.7168 & 5.48056 & .36701 \\
& SMA & 131 & 54.2990 & 6.11918 & .57499 \\
Achievment Identity & 80 & 54.2400 & 5.14288 & 1.35094 \\
& MA & 12 & 54.7559 & 4.67979 & .38139 \\
& SMK & 223 & 54.3024 & 5.69532 \\
\hline
\end{tabular}


Tabel 5

Distribusi skor Status Identitas berdasarkan Jurusan SMA

\begin{tabular}{llccrr}
\hline & & N & Mean & Std. Deviation & Std. Error \\
& & & & 5.30366 & .45312 \\
\multirow{3}{*}{ Diffuse Identity } & IPA & 137 & 45.8857 & 5.88570 & .77958 \\
& IPS & 57 & 45.7703 & 5.58996 & .36701 \\
& Lainnya & 29 & 44.8136 & 5.48056 & .49621 \\
& Total & 223 & 45.7168 & 5.80796 & .77648 \\
Achievment Identity & IPA & 137 & 54.0050 & 5.829 & .89930 \\
& IPS & 57 & 54.7121 & 5.84285 & 5.69532 \\
\hline
\end{tabular}

Tabel 6

Distribusi Skor Orientasi Masa Depan Berdasarkan Jenis Kelamin

\begin{tabular}{cccccc}
\hline & Jenis Kelamin & $\mathrm{N}$ & Mean & Std. Deviation & Std. Error Mean \\
\hline \multirow{2}{*}{ Orientasi Masa Depan } & $\mathrm{L}$ & 55 & 175.1406 & 26.25071 & 3.53965 \\
& $\mathrm{P}$ & 168 & 175.3787 & 22.06702 & 1.70251 \\
\hline
\end{tabular}

Selanjutnya adalah distribusi skor orientasi masa depan area pekerjaan berdasarkan semester yang diringkas dalam tabel berikut :

Tabel 7

Distribusi Skor Orientasi Masa Depan Berdasarkan Tingkat Semester Descriptives Orientasi Masa Depan

\begin{tabular}{crcrr}
\hline & N & Mean & Std. Deviation & Std. Error \\
& & & & \\
\hline 2 & 59 & 171.1009 & 22.43106 & 2.92028 \\
4 & 56 & 173.6167 & 25.53334 & 3.41204 \\
6 & 55 & 175.0317 & 22.00716 & 2.96744 \\
8 & 53 & 182.1156 & 21.33836 & 2.93105 \\
Total & 223 & 175.3200 & 23.10717 & 1.54737 \\
\hline
\end{tabular}

Dari data hasil output. analisis deskriptif tersebut, dapat dilihat bahwa semakin tinggi tingkat semester semakin tinggi rata-rata skor orientasi masa depan yang diperoleh. Rata-rata tertinggi untuk semester 8 dan terendah semester 2 .

Berikut ini adalah distribusi skor orientasi masa depan area pekerjaan berdasarkan usia subjek :
Tabel 8

Distribusi Skor Orientasi Masa Depan Berdasarkan Usia

Descriptives

Orientasi Masa Depan

\begin{tabular}{lrccr}
\hline & N & Mean & $\begin{array}{c}\text { Std. } \\
\text { Deviation }\end{array}$ & Std. Error \\
& & & & \\
\hline $17-19$ & 97 & 171.3661 & 23.80848 & 2.41739 \\
$20-21$ & 95 & 177.8466 & 22.24217 & 2.28200 \\
$>22$ & 31 & 179.9492 & 22.23183 & 3.99295 \\
Total & 223 & 175.3200 & 23.10717 & 1.54737 \\
\hline
\end{tabular}

Seperti halnya berdasarkan tingkat semester dari tabel 9. ini dapat terlihat bahwa rata-rata skor orientasi masa depan area pekerjaan meningkat seiring bertambahnya usia. Dari tabel diatas terlihat semakin bertambah usia semakin meningkat pula rata-rata skor orientasi masa depan. Rata-rata tertinggi berada pada usia $>22$ tahun dan terendah pada usia 17-19 tahun.

Kemudian distribusi skor orientasi masa depan area pekerjaan berdasarkan asal sekolah saat SMA diringkas dalam tabel berikut : 
Tabel 9

Distribusi Skor Orientasi Masa Depan Berdasarkan Asal Sekolah

Descriptives

Orientasi Masa Depan

\begin{tabular}{lrrrr}
\hline & N & Mean & $\begin{array}{c}\text { Std. } \\
\text { Deviation }\end{array}$ & Std. Error \\
& & & & \\
\hline SMA & 131 & 174.6331 & 22.80239 & 1.99225 \\
MA & 80 & 176.0523 & 24.21800 & 2.70766 \\
SMK & 12 & 177.9368 & 20.04601 & 5.78679 \\
Total & 223 & 175.3200 & 23.10717 & 1.54737 \\
\hline
\end{tabular}

Dari tabel diatas dapat dilihat bahwa mahasiswa yang asal sekolahnya dari SMK memiliki rata-rata skor orientasi masa depan area pekerjaan paling tinggi. Kemudian mahasiswa yang berasal dari SMA meliki rata-rata paling rendah.

Yang terakhir distribusi skor orientasi masa depan area pekerjaan ber-dasarkan jurusan saat SMA diringkas dalam tabel berikut:

Tabel 10

Distribusi Skor Orientasi Masa Depan Berdasarkan Jurusan SMA

Descriptives

Orientasi Masa Depan

\begin{tabular}{lrccc}
\hline & N & Mean & $\begin{array}{c}\text { Std. } \\
\text { Deviation }\end{array}$ & Std. Error \\
& & & & \\
\hline IPA & 137 & 174.8734 & 23.01511 & 1.96631 \\
IPS & 57 & 174.9771 & 23.93542 & 3.17032 \\
Lainnya & 29 & 178.1037 & 22.48412 & 4.17520 \\
Total & 223 & 175.3200 & 23.10717 & 1.54737 \\
\hline
\end{tabular}

Rata-rata skor orientasi masa depan area pekerjaan antara jurusan IPA dan IPS memiliki selisih yang sangat tipis. Namun rata-rata tertinggi berada di jurusan lainnya yaitu jurusan kegamaan ditambah jurusanjurusan yang ada di SMK.

\section{Hasil Analisis Inferensial \\ Uji kelayakan Model Regresi}

Pada Tabel 11 terdapat hasil perhitungan ANOVA menggunakan bantuan IBM SPSS 20.00 for windows. Dapat dilihat bahwa tingkat signifikansinya adalah 0.000. Agar dapat digunakan sebagai model regresi untuk memprediksi variabel dependen, maka angka signifikansi (sig) harus <0,05 (Santoso, 2012). Uji ANOVA pada tabel 12. menghasilkan tingkat signifikansi $0.000<0,05$, maka model regresi yang digunakan sudah layak untuk memprediksi orientasi masa depan area pekerjaan. Atau dapat dikatakan bahwa status identitas berpengaruh terhadap orientasi masa depan area pekerjaan.

\section{Koefisien Determinasi}

Koefisien determinasi dapat digunakan untuk melihat seberapa besar pengaruh variabel bebas terhadap variabel tergantung. Koefisien determinasi dapat dilihat dari $\mathrm{R}$ Square hasil perhitungan menggunakan aplikasi SPSS pada Tabel 12.

Dari Tabel 12 terlihat Achievement Identity, Foreclosure Identity, Moratorium Identity, Diffuse Identity secara bersama memiliki korelasi dengan orientasi masa depan sebesar 0,560. Hal ini dapat dilihat dari skor $\mathrm{R}$, dengan kata lain status identitas memiliki korelasi sebesar 0,560 dengan orientasi masa depan area pekerjaan. Korelasi antara orientasi masa depan dengan empat variabel independen status identitas adalah kuat, menurut Santoso (2012) hubungan kuat jika korelasinya diatas 0,5 . Selanjutnya apabila dilihat dari skor $\mathrm{R}$ Square dapat disimpulkan bahwa $31,4 \%$ variabel orientasi masa depan area pekerjaan dipengaruhi oleh variabel status identitas.

\section{Koefisien Regresi}

Koefisien regresi dapat digunakan untuk mengetahui angka konstan dan uji hipotesis signifikansi koefisien regresi. Hasil output perhitungan menggunakan SPSS dapat dilihat pada Tabel 13. 
Tabel 11

ANOVA

\begin{tabular}{|c|c|c|c|c|c|c|}
\hline Model & & Sum of Squares & $\mathrm{Df}$ & Mean Square & F & Sig. \\
\hline & Regression & 37231.098 & 4 & 9307.774 & 24.957 & $.000^{\mathrm{b}}$ \\
\hline \multirow[t]{2}{*}{1} & Residual & 81303.864 & 218 & 372.954 & & \\
\hline & Total & 118534.962 & 222 & & & \\
\hline $\begin{array}{l}\text { a. Depe } \\
\text { b. Predi } \\
\text { Foreclo }\end{array}$ & $\begin{array}{l}\text { dent Variable } \\
\text { tors: (Constar } \\
\text { sure, Identitas }\end{array}$ & $\begin{array}{l}\text { entasi Masa Depan } \\
\text { lentitas Achievemer } \\
\text { ratorium, Identitas D }\end{array}$ & $\begin{array}{l}\text { entitas } \\
\text { se }\end{array}$ & & & \\
\hline
\end{tabular}

Tabel 12

Koefisien Determinasi

Model Summary ${ }^{b}$

\begin{tabular}{ccccc}
\hline Model & $\mathrm{R}$ & R Square & Adjusted R Square & Std. Error of the Estimate \\
\hline 1 & $.560^{\mathrm{a}}$ & .314 & .302 & 19.31200 \\
\hline $\begin{array}{l}\text { a. Predictors: (Constant), Identitas Achievement, Identitas Foreclosure, Identitas Moratorium, Identitas Diffuse } \\
\text { b. Dependent Variable: Orientasi Masa Depan }\end{array}$
\end{tabular}

Tabel 13

Koefisien Regresi

\begin{tabular}{llccccc}
\multicolumn{7}{c}{ Coefficients $^{\mathbf{a}}$} \\
\hline \multirow{2}{*}{ Model } & \multicolumn{2}{c}{ Unstandardized Coefficients } & Standardized Coefficients & t & \multirow{2}{*}{ Sig. } \\
& B & Std. Error & Beta & & 7.790 & .000 \\
& (Constant) & 149.087 & 19.139 & -.230 & -3.524 & .001 \\
& Identitas Diffuse & -.969 & .275 & -.006 & -.105 & .916 \\
& Identitas Foreclosure & -.021 & .201 & -.135 & -2.137 & .034 \\
& Identitas Moratorium & -.626 & .293 & .468 & 8.131 & .000 \\
\hline
\end{tabular}

a. Dependent Variable: Orientasi Masa Depan

Persamaan analisis regresinya adalah:

$\ddot{Y}=a_{0}+a_{1} X_{1}+a_{2} X_{2}+a_{3} X_{3}+a_{4} X_{4}$

Keterangan :

$\ddot{Y}=$ Orientasi Masa Depan area Pekerjaan

$X_{1}=$ Diffuse Identity

$X_{2}=$ Foreclosure Identity

$X_{3}=$ Moratorium Identity

$X_{4}=$ Achievement Identity

$a_{0}=$ Angka konstan dari Unstandardized

Coefficients yang dalam penelitian ini adalah 149,087

$a_{1}=$ Angka koefisien regresi dari variabel $X_{1}$ yaitu sebesar (-) 0,969. Angka ini - memiliki arti bahwa setiap pengurangan 1 nilai pada identitas diffuse, orientasi masa depan area pekerjaan akan bertambah sebesar 0,969 .

$a_{2}=$ Angka koefisien regresi dari variabel $X_{2}$ yaitu sebesar (-) 0,021. Angka ini memiliki arti bahwa setiap pengurangan 1 nilai pada identitas foreclosure, orientasi masa depan area pekerjaan akan bertambah sebesar 0,021 .

$a_{3}=$ Angka koefisien regresi dari variabel $X_{3}$ yaitu sebesar (-) 0,626 . Angka ini memiliki arti bahwa setiap 
pengurangan 1 nilai pada identitas moratorium, orientasi masa depan area pekerjaan akan bertambah sebesar 0,626 .

$a_{4}=$ Angka koefisien regresi dari variabel $X_{4}$ yaitu sebesar 1,898. Angka ini memiliki arti bahwa setiap penambahan 1 nilai pada identitas achievement, orientasi masa depan area pekerjaan akan berkurang sebesar 1,898 .

Sehingga persamaannya menjadi :

$$
\begin{aligned}
& \ddot{Y}=149,087+(-) 0,969 X_{1}+(-) 0,021 X_{2} \\
& +(-) 0,626 X_{3}+1,8598 X_{4}
\end{aligned}
$$

Untuk mengetahui apakah koefisien regresi signifikan atau tidak, maka peneliti menggunakan uji $\mathrm{t}$ untuk menguji signifikansi konstanta dan variabel status identitas yang digunakan sebagai prediktor untuk orientasi masa depan area pekerjaan. Uji $t$ ini juga sekaligus dapat digunakan untuk menguji hipotesis penelitian yang telah diajukan. Kriteria uji untuk uji $t$ adalah $H_{0}$ ditolak , jika $t_{\text {hitung }}>t_{\text {tabel }}$ atau $p_{v}<\alpha$.

Dari tabel 14 dapat dilihat bahwa skor $p_{v}$ (sig) dari identitas diffuse adalah 0,001 < 0,05, maka $H_{0}$ ditolak dan $H_{1}$ diterima. Artinya identitas diffuse berpengaruh signifikan terhadap orientasi masa depan area pekerjaan. Selanjutnya skor $p_{v}(\mathrm{sig})$ dari identitas foreclosure adalah 0,916 > 0,05, maka $H_{0}$ diterima dan $H_{1}$ ditolak. Artinya identitas foreclosure tidak berpengaruh terhadap orientasi masa depan area pekerjaan. Kemudian skor $p_{v}(\mathrm{sig})$ dari identitas moratorium adalah 0,034 < 0,05, maka $H_{0}$ ditolak dan $H_{1}$ diterima. Artinya identitas moratorium berpengaruh signifikan terhadap orientasi masa depan area pekerjaan. Yang terakhir skor $p_{v}(\mathrm{sig})$ dari identitas achievement adalah 0,000 < 0,05, maka $H_{0}$ ditolak dan $H_{1}$ diterima. Artinya identitas achievement berpengaruh signifikan terhadap orientasi masa depan area pekerjaan.

Pada tabel 14 di kolom Standardized Coefficients terlihat bahwa skor yang paling tinggi adalah skor identitas achievement yaitu sebesar 0,468. Hal tersebut menandakan bahwa identitas avhievement lebih dominan dari pada identitas lainnya dalam mempengaruhi orientasi masa depan area pekerjaan.

Dari penjelasan sebelumnya diketahui bahwa variabel identitas foreclosure memiliki angka $p_{v}(\mathrm{sig})>0,05$ yaitu 0,916 .

Karena itu, variabel tersebut sebenarnya tidak mempengaruhi orientasi masa depan area pekerjaan. Dengan demikian, variabel identitas foreclosure dikeluarkan dari model regresi, kemudian prosedur pencarian model regresi diulang lagi untuk mendapatkan hasil yang lebih pasti.

Dengan demikian model regresi yang benar adalah

$\ddot{Y}=148,577+(-) 0,978 X_{1}+(-) 0,628 X_{2}$ $+1,899 X_{3}$

Pengaruh Jenis Kelamin, Usia, Tingkat Smester, Asal Sekolah Dan Jurusan Saat SMA Terhadap Orientasi Masa Depan Area Pekerjaan.

Selain empat variabel independen yang telah dibahas sebelumnya, peneliti juga ingin mengetahui pengaruh variabel moderator lainnya yang menjadi gambaran umum subjek penelitian. Variabel-variabel tersebut adalah jenis kelamin, tingkat semester, usia, asal sekolah dan jurusan saat SMA. Apakah variabel-variabel yang sudah ada dalam diri subjek tersebut memberikan pengaruh terhadap orientasi masa depan area pekerjaan. Hasil perhitungan SPSS tersebut diringkas dalam Tabel 15.

Dari hasil skor (Tabel 15) $p_{v}$ atau (sig) terlihat bahwa skor $p_{v}$ atau (sig) dari variabel moderator semuanya $>0,05$. Hal tersebut memiliki arti bahwa variabel moderator tersebut tidak memberikan 
pengaruh yang signifikan terhadap variabel orientasi masa depan area pekerjaan. Jenis kelamin, tingkatan semester, usia, asal sekolah dan jurusan saat SMA tidak memberikan pengaruh yang signifikan terhadap orientasi masa depan area pekerjaan.

\section{Hubungan Status Identitas dengan Orientasi Masa Depan Area Pekerjaan.}

Kemudian peneliti juga ingin membahas koefisien korelasi dari hasil perhitungan menggunakan SPSS antara variabel status identitas dengan orientasi masa depan area pekerjaan (Tabel 16).

Dari tabel 16 dapat dilihat bahwa hasil Sig. (1-tailed)nya semua lebih kecil dari 0,05 . Hal tersebut berarti bahwa keempat status identitas memiliki hubungan yang signifikan dengan orientasi masa depan area pekerjaan. Hubungan tersebut signifikan dengan $\alpha=0,05$ dan arah hubungannya satu arah.

\section{Hubungan Orientasi Masa Depan Dengan Prestasi Akademik Pada Mahasiswa Fakultas Psikologi UIN Sunan Gunung Djati Bandung.}

Peneliti tertarik untuk melihat hubungan orientasi masa depan area pekerjaan dengan prestasi akademik mahasiswa yang dilihat dari IPK (Tabel 17). Dari tabel 17 tersebut terlihat bahwa tidak ada hubungan yang signifikan antara orientasi masa depan area pekerjaan dengan prestasi akademik mahasiswa. Hal tersebut terlihat dari $p_{v}=0,446>0,05$ yang berarti tidak ada hubungan yang signifikan.

\section{Pembahasan}

Sesuai dengan tujuan penelitian yang telah dikemukakan diawal bahwa penelitian ini bertujuan untuk mengetahui gambaran status identitas dan orientasi masa depan area pekerjaan serta melihat pengaruh status identitas terhadap orientasi masa depan area pekerjaan pada mahasiswa Fakultas Psikologi UIN Sunan Gunung Djati Bandung. Untuk itu dalam bagian ini peneliti akan melakukan pembahasan terhadap hasil penelitian untuk menjawab rumusan masalah yang telah dikemukakan di awal.

Untuk yang pertama peneliti akan membahas mengenai gambaran status identitas pada mahasiswa Fakultas Psikologi UIN Sunan Gunung Djati Bandung berdasarkan jenis kelamin, tingkat semester, usia, asal sekolah dan jurusan saat SMA. Dari lima variabel diatas bila dilihat dari skor rata-ratanya, hanya 2 variabel yang rata-ratanya memiliki dinamika perbedaan. Dua variabel tersebut adalah variabel usia dan tingkat semester.

Sebagai contoh pada identitas diffuse skor rata-ratanya semakin menurun seiring bertambahnya usia. Pada usia 17-19 tahun skor rata-ratanya adalah 46,69, untuk usia 20-21 skor rata-ratanya 45,11 , dan skor rata-rata usia 22 tahun keatas adalah 44,49. Kemudian untuk contoh hasil perhitungan berdasarkan tingkat semester skor rataratanya semakin meningkat seiring bertambahnya tingkat semester. Rata-rata skor untuk identitas achievement pada semester 2 adalah 53,60, pada semester 4 adalah 53,79, kemudian pada semester 6 adalah 54,51, dan pada semester 8 adalah 55,40 . Selanjutnya rata-rata berdasarkan usia pada identitas achievement adalah 53,76 pada usia 17-19 tahun, 54,62 pada usia 20-21 dan 55,01 pada usia 22 tahun keatas. Dari data diatas peneliti berasumsi bahwa semakin bertambahnya usia dan tingkat semester akan terjadi perubahan identitasnya. Hal ini sesuai dengan hasil penelitian Meilman (1979) dan Archer (1982) terhadap laki-laki yang berusia 1224 tahun ditemukan bahwa tidak ada identitas Achievement dan Moratorium pada responden usia 12 tahun dan hanya 4\% pada usia 15 tahun, identitas achievement dan moratorium mulai terlihat secara 
Tabel 14

Coefficients $^{\mathrm{a}}$

\begin{tabular}{lccccc}
\hline Model & \multicolumn{2}{c}{ Unstandardized Coefficients } & Standardized Coefficients & T & Sig. \\
& B & Std. Error & Beta & & \\
\hline (Constant) & 148.577 & 18.474 & & 8.043 & .000 \\
1 & $-.978-$ & .262 & $-.232-$ & $-3.733-$ & .000 \\
Diffuse Identity & $-.628-$ & .292 & $-.135-$ & $-2.151-$ & .033 \\
& Moratorium Identity & -233 & .468 & 8.152 & .000 \\
\hline
\end{tabular}

a. Dependent Variable: Orientasi Masa Depan

Tabel 15

Koefisien Regresi Variabel Moderator

Coefficients $^{\mathrm{a}}$

\begin{tabular}{|c|c|c|c|c|c|c|}
\hline & \multirow[t]{2}{*}{ Model } & \multicolumn{2}{|c|}{ Unstandardized Coefficients } & \multirow{2}{*}{$\begin{array}{c}\text { Standardized Coefficients } \\
\text { Beta }\end{array}$} & \multirow[t]{2}{*}{$\mathrm{T}$} & \multirow[t]{2}{*}{ Sig. } \\
\hline & & B & Std. Error & & & \\
\hline \multirow{10}{*}{1} & (Constant) & 146.987 & 21.457 & & 6.850 & .000 \\
\hline & Diffuse Identity & $-.998-$ & .289 & $-.237-$ & $-3.452-$ & .001 \\
\hline & Foreclosure Identity & $-.002-$ & .208 & .000 & $-.008-$ & .994 \\
\hline & Moratorium Identity & $-.623-$ & .298 & $-.134-$ & $-2.092-$ & .038 \\
\hline & Achievment Identity & 1.892 & .237 & .466 & 7.976 & .000 \\
\hline & Jenis Kelamin & $-.948-$ & 3.148 & $-.018-$ & $-.301-$ & .764 \\
\hline & Tingkat Semester & $-1.498-$ & 2.133 & $-.073-$ & $-.702-$ & .483 \\
\hline & Usia & 3.900 & 3.319 & .118 & 1.175 & .241 \\
\hline & Asal Sekolah & 1.671 & 2.530 & .043 & .661 & .510 \\
\hline & Jurusan SMA & $-.696-$ & 2.132 & $-.022-$ & $-.326-$ & .744 \\
\hline
\end{tabular}

a. Dependent Variable: Orientasi Masa Depan

Tabel 16

Kefisien Korelasi

Correlations

\begin{tabular}{llc}
\hline & Correlations & Orientasi Masa Depan \\
\hline \multirow{4}{*}{ Pearson Correlation } & 1.000 \\
& Orientasi Masa Depan & -.324 \\
& Identitas Diffuse & -.126 \\
& Identitas Foreclosure & -.156 \\
& Identitas Moratorium & .465 \\
& Identitas Achievement &. \\
& Orientasi Masa Depan & .000 \\
Sig. (1-tailed) & Identitas Diffuse & .030 \\
& Identitas Foreclosure & .010 \\
& Identitas Moratorium & .000 \\
& Identitas Achievement & 223 \\
& Orientasi Masa Depan & 223 \\
$\mathrm{~N}$ & Identitas Diffuse & 223 \\
& Identitas Foreclosure & 223 \\
& Identitas Moratorium & 223 \\
\hline
\end{tabular}

Tabel 17

Korelasi dengan IPK

\begin{tabular}{llcc}
\multicolumn{4}{c}{ Correlations } \\
\hline & & Orientasi Masa Depan & IPK \\
\hline \multirow{3}{*}{ Orientasi Masa Depan } & Pearson Correlation & 1 & $-.009-$ \\
& Sig. (1-tailed) & & .446 \\
& $\mathrm{~N}$ & 223 & 223 \\
$\mathrm{IPK}$ & Pearson Correlation & $-.009-$ & 1 \\
& Sig. (1-tailed) & .446 & \\
& $\mathrm{~N}$ & 223 & 223 \\
\hline
\end{tabular}


signifikan pada usia 18 tahun dan meningkat hingga usia 24 tahun, serta terlihat jelas perubahannya dari rendah ketinggi terjadi sekitar usia 21-22 tahun (Marcia ,1993). Hasil penelitian tersebut sejalan dengan hasil wawancara yang dilakukan pada bulan april tahun 2015 ketika ditanya mengenai alasan memilih jurusan psikologi "Mungkin di awalnya bukan maksud utama masuk jurusan psikologi, Pada awalnya saya berminat di jurusan seni musik, sejarah dan jurusan sosiologi. Nah ketika itu Psikologi UIN sebagai alternatif terakhir. Saat menginjak semester 2 saya pernah mencoba fokus ke SNMPTN untuk mengejar jurusan yang saya inginkan yaitu seni musik sehingga IP saya menjadi turun. Karena saya merasa memiliki passion ke jurusan seni musik dan belum memiliki gambaran yang jelas terhadap jurusan psikologi yang sedang saya jalani. Karena tidak diterima dijurusan seni musik saat mengikuti SNMPTN sedangkan saya sudah menginjak semester 3 di psikologi akhirnya tidak ada pilihan lain selain mempertahankan apa yang sudah saya jalani di jurusan Psikologi”. Berdasarkan hasil wawancara tersebut peneliti berpendapat hal ini terjadi dikarenakan adanya proses eksplorasi seiring bertambahnya usia dan semester.

Dari jawaban wawancara tersebut peneliti melihat bahwa seiring bertambahnya semester mahasiswa memilik kesempatan untuk bereksplorasi terhadap jurusan psikologi. Kemudian dari eksplorasi tersebut mahasiswa akhirnya akan menentukan komitmennya. Dalam kasus ini adalah apakah ia tetap di psikologi atau keluar dari psikologi.

Selanjutnya peneliti akan membahas mengenai gambaran orientasi masa depan area pekerjaan pada mahasiswa Fakultas Psikologi UIN Sunan Gunung Djati Bandung berdasarkan jenis kelamin, tingkat semester, usia, asal sekolah dan jurusan saat SMA. Dari lima variabel diatas untuk rata-rata skor orientasi masa depan berdasarkan jenis kelamin selisihnya sangat tipis yaitu 0,23 saja, rata-rata skor untuk laki-laki adalah 175,14 dan perempuan adalah 175,37. Hal ini sama seperti tidak ada perbedaan karena selisihnya sangat kecil.

Selanjutnya untuk rata-rata skor berdasarkan usia dan tingkat semester memiliki kesamaan pola yaitu semakin bertambah usia atau tingkat semester skor rata-rata orientasi masa depan semakin meningkat. Berikut sebagai contoh skor rata-rata orientasi masa depan berdasarkan tingkat semester. Pada semester 2 rataratanya 171,10 , semester 4 rata-ratanya 173,61 , semester 6 rata-ratanya 175,03, dan pada semester 8 rata-ratanya 182,11 . Peneliti berpendapat orientasi masa depan meningkat seiring bertambahnya usia karena pengaruh status identitas. Karena status identitas juga meningkat seiring bertambahnya usia, seperti yang telah dijelaskan sebelumnya identitas achievement dan moratorium mulai terlihat secara signifikan pada usia 18 tahun dan meningkat hingga usia 24 tahun, serta terlihat jelas perubahannya dari rendah ketinggi terjadi sekitar usia 21-22 tahun (Marcia ,1993).

Kemudian skor rata-rata berdasarkan asal sekolah dan jurusan saat SMA. Berdasarkan asal sekolah rata-rata tertinggi berada pada skor rata-rata yang asal sekolahnya dari SMK. Dengan skor masingmasing 174,63 untuk SMA, 176,05 untuk MA, dan skor tertinggi 177,91 untuk SMK. Jika berdasarkan jurusan saat SMA ratarata tertinggi berada pada jurusan lainnya (keagamaan dan jurusan SMK). Dengan skor rata-rata masing-masing jurusan IPA 174,87, jurusan IPS 174,97, dan jurusan lainnya (keagamaan dan jurusan SMK) 178,10 .

Untuk mahasiswa yang berasal dari SMK memiliki skor rata-rata yang lebih tinggi dikarenakan SMK dari awal memang sudah terfokus pada suatu keahlian tertentu. Jadi mahasiswa yang berasal dari SMK memang sudah diarahkan untuk memiliki keahlian tertentu untuk bidang pekerjaan 
tertentu pula. Sedangkan yang berasal dari SMA dan MA memang diarahkan untuk mempelajari pelajaran yang lebih luas dan belum terlalu fokus pada keahlian dalam bidang tertentu. Jurusan yang ada di SMA dan MA masih tergolong umum belum spesifik menjurus pada keahlian tertentu. Demikian halnya untuk jurusan lainnya (keagamaan dan jurusan SMK) memiliki skor yang lebih tinggi dikarenakan alasan yang sama.

Dari hasil uji kelayakan model regresi diperoleh $\mathrm{F}$ hitung $=24,95$ dengan signifikansi $0,000<0,05$. Hal tersebut menunjukkan bahwa model regresi sudah bisa dipakai untuk memprediksi orientasi masa depan. Dapat dikatakan bahwa keempat identitas atau status identitas berpengaruh terhadap orientasi masa depan. Selain itu skor R square atau koefisien determinasi adalah 0,314 atau sama dengan $31,4 \%$. Artinya $31,4 \%$ variasi dari orientasi masa depan dipengaruhi oleh status identitas. Sisanya $68,6 \%$ dipengaruhi oleh faktor-faktor lain. Hal ini sejalan dengan hasil penelitian kualitatif Flores-Crespo (2007 dalam Jelenic, M., 2013) yang dilakukan terhadap 48 siswa dan 32 guru, Flores-Crespo menemukan bahwa identitas mempengaruhi tingkah laku di kelas dan juga mempengaruhi pandangan terhadap orientasi masa depan tentang pilihan sekolah dan preferensi karir.

Dari hasil uji hipotesis menggunakan uji $\mathrm{t}$ menunjukkan bahwa dari keempat identitas, identitas foreclosure tidak memberikan pengaruh yang signifikan terhadap orientasi masa depan. Dengan $p_{v}$ sebesar $0,916>0,05$ maka $H_{0}$ diterima, artinya identitas foreclosure tidak berpengaruh terhadap orientasi masa depan. Untuk tiga status lainnya memiliki $p_{v}<0,05$, maka tiga status lainnya memberikan pengaruh yang signifikan.

Menurut Santrock (2012) Identity foreclosure adalah status individu yang sudah membuat komitmen namun sebenarnya tidak pernah mengalami krisis. Status identitas ini biasanya terjadi ketika orang tua menurunkan komitmen pada anaknya, biasanya secara otoriter, sebelum anak tersebut memiliki kesempatan untuk mengeksplorasi berbagai pendekatan, ideologis, dan pekerjaannya sendiri (Santrock,2012). Karena komitmen yang dimiliki identitas foreclosure merupakan hasil turunan dari orang tua atau mengikuti orang tua, maka seseorang belum sempat melakukan eksplorasi.

Dalam orientasi masa depan seseorang diperlukan eksplorasi sebelum menentukan memilih satu bidang pekerjaan yang ingin dicapai dimasa depan, untuk menyusun rencana dan mengevaluasinya. Menurut Marcia dan Archer (Marcia, 1993) setiap keputusan mengenai pekerjaan sangat dipengaruhi oleh orang dewasa atau orang tua, dari awal mereka kurang memperoleh eksplorasi , mereka kehilang-an peluang untuk mengeksplorasi potensi yang mereka miliki mengenai bidang pekerjaan. Peneliti berpendapat mahasiswa dengan skor identitas foreclosure tinggi memiliki dua kemungkinan dalam orientasi masa depan area pekerjaan, yaitu mereka sudah menentukkan pilihannya sesuai keinginan orang tua atau belum bisa memutuskan tanpa pendapat orang tua. Kemudian mahasiswa yang memiliki skor rendah pada identitas foreclosure juga memiliki dua kemungkinan, yaitu mereka sudah dapat menentukan pilihannya dengan eksplorasi yang dilakukan sendri atau mereka belum bisa menentukan komit-mennya. Karena hal tersebutlah kemung-kinan identitas foreclosure tidak berpe-ngaruh terhadap orientasi masa depan.

Meskipun identitas foreclosure tidak memberikan pengaruh yang signifikan terhadap orientasi masa depan, namun dari hasil koefisien korelasi menunjukkan bahwa identitas diffuse memiliki hubungan yang signifikan dengan orientasi masa depan. Hal ini terlihat hari nilai $p_{v}=0,030>$ 0,05 , meskipun korelasinya sangat rendah yaitu -0.123. Identitas foreclosure berhubungan dengan orientasi masa depan, namun hubungannya tidak cukup untuk 
memberikan pengaruh terhadap orientasi masa depan area pekerjaan.

Menurut Santrock (2012) identitas achievement status individu yang sudah mengalami krisis dan sudah membuat komitmen. Hasil skor dari uji t diperoleh $p_{v}=0,00<0,05$ dan koefisien korelasi dengan orientasi masa depan 0,465. Dari hasil tersebut menunjukkan bahwa identitas achievement memberikan pengaruh yang signifikan terhadap orientasi masa depan dan memiliki hubungan yang positif meskipun korelasinya lemah. Artinya semakin tinggi identitas achievement maka semakin tinggi orientasi masa depan dan begitu pula sebaliknya. Seseorang yang memiliki identitas achievement tinggi sudah bisa menantukan komitmennya melalui hasil eksplorasinya. Hal ini tentunya mempengaruhi pemilihan karir mereka, pembuatan perencanaan dan mereka sudah dapat melakukan evaluasievaluasi terhadap perncanaannya. Sejalan dengan Marcia dan Archer (Marcia, 1993) yang menyatakan orang yang memiliki identitas achievement akan dengan serius melakukan eksplorasi paling tidak pada satu alternatif pada pekerjaan yang dippilih dan akan mulai berpikir bahwa diri mereka menjabat suatu pekerjaan tertentu (misal: guru, dokter, dll).

Selanjutnya untuk hasil skor uji t pada identitas moratorium diperoleh $p_{v}=0,034<$ 0,05 dan koefisien korelasi dengan orientasi masa depan -0,156. Identitas moratorium mempengaruhi orientasi masa depan dan memiliki hu-bungan yang signifikan meskipun kore-lasinya lemah. Korelasi negatif artinya semakin tinggi identitas moratorium maka orientasi masa depan semakin berkurang. Menurut Santrock (2012) identitas moratorium status individu yang sedang dalam pertengahan krisis dan belum menentukan komitmennya. Menurut Marcia dan Archer (Marcia, 1993) pada identitas moratorium seseorang harus terlibat dan harus dengan aktif mengeksplorasi alternatif-alternatif yang berhubungan dengan tujuannya sampai me- nemukan komitmen dalam bidang pekerjaan yang diinginkan. Peneliti berasumsi hubungannya negatif dikarenakan jika skor identitas moratorium mereka tinggi, maka mereka belum memiliki komitmen. Sedangkan orientasi masa depan memerlukan komitmen untuk menentukkan pilihan dan penyusunan perencanaan. Jadi jika skor identitas moratorium tinggi skor orientasi masa depan tidak mengikuti tinggi.

Kemudian hasil skor uji $t$ pada identitas diffuse diperoleh $p_{v}=0,001<0,05$ dan koefisien korelasi dengan orientasi masa depan -0,324. Identitas diffuse mempengaruhi orientasi masa depan dan memiliki hubungan yang signifikan meskipun korelasinya lemah. Korelasi negatif artinya semakin tinggi identitas diffuse maka orientasi masa depan semakin berkurang. Menurut Santrock (2012) identitas diffuse adalah status seseorang yang beleum pernah mengalami krisis ataupun membuat komitmen, mereka belum membuat keputusan menyangkut pilihan pekerjaan atau ideologi dan mereka juga cenderung kurang berminat pada hal tersebut. Marcia dan Archer (Marcia, 1993) menyatakan bahwa orang dengan identitas diffusion biasanya kurang memiliki komitmen dan mereka mungkin belum mengalami periode eksplorasi atau jika mereka sudah mengalaminya, itupun biasanya dangkal dan singkat Peneliti berpendapat bahwa hubungan yang negatif dikarenakan mahasiswa yang skor identitas diffusenya tinggi mereka belum membuat keputusan mengenai pekerjaan dan kurang tertarik pada hal tersebut atau mungkin belum memikirkan hal tersebut. Jadi skor orientasi masa depan rendah dikarenakan mereka belum memiliki perencanaan untuk masa depannya atau mereka belum tertarik untuk merencanakannya.

Selain variabel status identitas peneliti juga ingin mengetahui pengaruh dari variabel moderator lain seperti jenis kelamin, tingkat semester usia, asal sekolah dan jurusan saat SMA. Dari hasil uji $t$ 
didapatkan untuk semua variabel tersebut memiliki skor $p_{v}>0,05$, yang berati bahwa kelima variabel tersebut tidak memberikan pengaruh yang signifikan terhadap orientasi masa depan area pekerjaan. Hal ini dikarenakan dalam penentuan orientasi masa depan lebih dipengaruhi bagaimana seseorang dapat mengambil keputusan dan menyusun perencanaan. Atau bisa dikatakan bahwa orientasi masa depan lebih pada proses psikologis yang ada dalam diri individu.

Kemudian peneliti juga tertarik untuk melihat hubungan antara orientasi masa depan dengan prestasi akademik mahasiswa. Hasilnya adalah peneliti menemukan bahwa tidak ada hubungan yang signifikan antara orientasi masa depan area pekerjaan dengan prestasi akademik mahasiswa. Hal tersebut terlihat dari $p_{v}=0,446>0,05$ yang berarti tidak ada hubungan yang signifikan. Apa yang ditemukan peneliti sejalan penelitian Greene (1986 dalam Nurmi, 1991) yang tidak menemukan korelasi antara hasil pengukuran operasional formal menggunakan Piagetian-type dan koherensi pemikiran masa depan. Kemudian Nurmi menyatakan hasil penelitian menunjukkan korelasi yang rendah atau tidak ada hubungan antara kemampuan kognitif dan level perencanaan masa depan (Nurmi,1991).

\section{Simpulan dan Saran}

Berdasarkan hasil analisis data dan pengujian hipotesis yang telah dikemukakan sebelumnya, maka kesimpulan yang dapat diambil dari penelitian ini adalah "Terdapat pengaruh yang signifikan dari status identitas terhadap orientasi masa depan area pekerjaan". Namun dari empat status identitas hanya tiga identitas yang memberikan pengaruh signifikan terhadap orientasi masa depan area pekerjaan, yaitu identitas achievement, identitas moratorium, dan identitas diffuse. Sedangkan identitas foreclosure tidak memberikan pengaruh yang signifikan. Meskipun demikian identitas foreclosure memiliki hubungan yang signifikan dengan orientasi masa depan area pekerjaan.

Selain itu hasil pengujian terhadap variabel moderator lainnya seperti jenis kelamin, usia, tingkat semester, asal sekolah dan jurusan saat SMA, menunjukkan bahwa variabel tersebut tidak memiliki pengaruh yang signifikan terhadap orientasi masa depan area pekerjaan. Kemudian hasil uji korelasi antara orientasi masa depan dan prestasi akademik mahasiswa, hasilnya tidak terdapat hubungan yang sigfikan antara orientasi masa depan area pekerjaan dengan prestasi akademik mahasiswa.

Penulis menyadari bahwa dalam penelitian ini masih jauh dari kesempurnaan, masih banyak kekurangan dan kelemahannya. Namun hal tersebut merupakan pengalaman dan pembelajaran yang sangat berharga bagi peneliti. Berdasarkan hasil penelitian dan pengalaman peneliti saat mengerjaan penelitian ini, maka dapat diberikan beberapa saran sebagai berikut :

\section{Saran Metodologis}

Dikarenakan variasi dari status identitas hanya menyumbang pengaruh sebesar 31,4 \%, maka disarankan untuk penelitian selanjutnya agar mencari dan menghubungkan faktor-faktor lain yang mempengaruhi orientasi masa depan area pekerjaan.

Konstruk orientasi masa depan dapat diaplikasikan pada domain kehidupan lainnya. Oleh karena itu, dapat dila-kukan penelitian mengenai orientasi masa depan dalam domain kehidupan lainnya (misalnya: dalam bidang pendidikan, keluarga, pernikahan dan lainnya).

Populasi dalam penelitian ini hanya mahasiswa yang berada di Fakultas Psikologi UIN Sunan Gunung Djati Bandung. Untuk penelitian selanjutnya disarankan agar menggunakan populasi yang lebih luas agar mendapatkan hasil yang lebih variatif. 
Selanjutnya diharapkan mengadakan penelitian orientasi masa depan area pekerjaan pada responden dengan karakteristik yang berbeda (misalnya anak jalanan).

Salan satu kekurangan dari penelitian ini adalah alat ukur variabel status identitas merupakan hasil adaptasi dari alat ukur berbahasa inggris, oleh karena itu hasil tejemahan peneliti masih banyak yang rancu dan sulit dipahami responden. Terlihat dari hasil uji validitas masih ada beberapa item dalam skala tersebut yang belum valid. Untuk penelitian selanjutnya disaran-kan untuk membuat alat ukur yang lebih sederhana bahasanya sehingga mudah dimengerti oleh responden namun tetap valid.

Dan karena alat ukur variabel status identitas dalam setiap itemnya menggambarkan dua dimensi sekaligus. Maka dalam penelitian selanjutnya disarankan alat ukurnya setiap item hanya menggambarkan satu dimensi saja, agar dapat dilihat dalam analisis data dimensi apa yang paling ber-pengaruh terhadap orientasi masa depan.

\section{Saran Praktis}

Mengingat pentingnya orientasi masa depan area pekerjaan bagi mahasiswa, maka peneliti menyarankan;

Bagi institusi tempat dimana mahasiswa tersebut berkuliah, dalam hal ini Fakultas Psikologi UIN Bandung. Diharapkan agar memberikan bimbingan bagi mahasiswanya agar mahasiswa tersebut dapat mencapai identitas achievement. Proses bimibingan dapan dilakukan melalui dosen akademik masingmasing, disela-sela bimbingan KRS, diharapkan dosen pembimbing memberikan bimbingan mengenai pilihan mahasiswa terhadap domain-domain identitas (misalnya:pekerjaan, pertemanan, agama, politik dan lain sebagainya). Selain hal tersebut juga diharapkan agar dosen pembimbing memberikan arah bagi mahasiswanya dalam pemilihan karir di masa depan.

Fakultas Psikologi UIN Sunan Gunung Djati Bandung memiliki UPT. Layanan Psikologi yang terbuka bagi umum dan mahasiswa UIN sendiri. Diharapkan UPT. Layanan Psikologi tersebut mengadakan progam khusus mengenai bimbingan pemilihan karir khususnya bagi Mahasiswa Fakultas Psikologi.

Untuk para mahasiswa agar lebih melakukan eksplorasi dan mencari informasi sebanyak-banyaknya menge-nai bidang pekerjaan yang diinginkan di masa depan. Hal tersebut sedini mungkin sejak mahasiswa masuk kuliah seharusnya sudah dilakukan. Agar jika mahasiswa merasa jurusan yang sedang dijalani tidak sesuai dengan pekerjaan yang diinginkan, maka, mahasiswa dapat memilih ju-rusan lain yang sesuai dengan minat sedini mungkin. Sebaliknya jika ju-rusan Psikologi sudah sesuai cita-cita dimasa depan, mahasiswa harus segera mencari banyak informasi sejak dini untuk menunjang cita-citanya tersebut, khusunya dalam bidang pekerjaan.

\section{Daftar Pustaka}

Beal, S.J. 2011. The Development of Future

Orientation: Underpinnings and Related Constructs. Beal, Sarah J., "The Development of Future Orientation: Underpinnings and Related Constructs" (2011). Theses, Dissertations, and Student Research: Department of Psychology. Paper 32. http://digitalcommons.unl.edu/psychdis s/32. University of Nebraska Lincoln.

Feist \& Feist (2010). Teori Kepribadian ; Theories of Personality. Buku 1 edisi 7. (Penerjemah: Handrianto). Salemba Humanika: Jakarta

Friedenberg, L., 1995. Psychological Testing :Design, Anayisis, and Use.Allyn \& Bacon: United States of America.

Hurlock, E.B., 1980. Psikologi Perkembangan: Suatu Pendekatan 
Sepanjang Rentang Kehidupan. Ed. 5. Alih bahasa: Istiwidayanti \& Soedjarwo. Penerbit Erlangga :Jakarta Jahja, Y. 2011. Psikologi Perkembangan. Kencana: Jakarta

Nurmi, J.E. 1991 (Sullivan and Graham briefs) How Do Adolescents See Their Future? A Review of the Development of Future Orientation and Planning. University of Helsinki. Steinberg L, 2009. Science on Adolescent Development : Adolescent Development and Juvenile Justice.

Jelenic, M., 2013. Identity Status: The Impact on Academic Performance. Jelenic, Milan, "Identity Status: The Impact on Academic Performance" (2013). UNLV Theses/Dissertations/ Professional Papers/Capstones. Paper 1933. University of nevada, Las vegas

Marcia, J., Waterman A.S., Matteson, D.R. S.L. Archer, J.L. Orlofsky. 1993. Ego Identity a Handbook for Psychosocial research. Springer:Verlag : New York Inc.

Mushaf Al-Burhan. 2010. Majlis Ta'lim Al Burhan: Bekasi

Santoso, S. 2012. Aplikasi SPSS pada Statistik Parametrik. PT. Elex Media Komputindo : Jakarta.
Santrock, J.W. 2012. Life Span development;Perkembangan Masa Hidup. Ed 13 jilid 1. Penerbit Erlangga. Penerjemah: Benedictine Widyasinta

Seginer, R. 2003. Adolescent Future Orientation: An Integrated Cultural and Ecological Perspective. Seginer, R. . Adolescent Future Orientation: An Integrated Cultural and Ecological Perspective. Online Readings in Psychology and Culture, 6(1). http://dx.doi.org/10.9707/23070919.1056.

Sugiyono, 2012. Metode Penelitian Kombinasi (Mixed Methods). Alfabeta: Bandung.

UNDANG-UNDANG REPUBLIK INDONESIANOMOR 12 TAHUN 2012 TENTANG PENDIDIKAN TINGGI

Utami, T.P. 2012. Hubungan antara Status Identitas dengan Orientasi Masa Depan area Pendidikan pada Siswa Kelas XII SMA Negeri 2 Sumedang. Skripsi tidak dipublikasikan, Fakultas Psikologi UIN Sunan Gunung Djati, Bandung. 